\title{
ADVERTISING IN THE AGE OF HYPER CONSUMPTION
}

\author{
V.Stanev* \\ Department of Marketing and International Economic Relations, Faculty of Economic and \\ Social Sciences, Plovdiv University "Paisii Hilendarski”, Plovdiv, Bulgaria
}

\begin{abstract}
Countries with highly developed economies have allegedly entered the postmodern era during the 1950s. According to some researchers, however, such statement is incorrect because it implies equality between postmodernism and the third phase of hyper consumption capitalism. Regardless of this debate, advertising and promotion are characterized by different functions, tasks and goals compared to previous decades. This article is an attempt such peculiarities to be displayed and described.
\end{abstract}

Key words: advertising, hyper consumption capitalism, postmodernism, advertising functions

\section{INTRODUCTION}

A series of recent publications written by the author focuses on the economic and cultural arguments for the establishment of a correct periodization of Modernism and Postmodernism, including the respective consumer dominant logics, the added functions of marketing communications, and the power of advertising. It also draws on advertising as a form of power in the postmodern global, but also glocal world (1-5). This article comes as a natural continuation of the previous works and it attempts to find answer to the question whether advertising in the times of smart phones and online social networks is more powerful than before. The author also exposes some of the most prominent advertising markers in the third stage of consumer capitalism - the hyper consumption society but despite his findings, the aim of his research is not to impose declaratory imperatives but rather to highlight issues for further exploration.

\section{THE PERIODS OF CONSUMER CAPITALISM}

The first period of consumer capitalism began around the $80 \mathrm{~s}$ of $19^{\text {th }}$ century with the establishment of brand new transport and communication infrastructures in terms of their quantity and quality, the emergence of big

\footnotetext{
*Correspondence to: Velin Stanev, Department of Marketing and International Economic Relations, Faculty of Economic and Social Sciences, Plovdiv University "Paisii Hilendarski", Plovdiv 4000,

Bulgaria, 24 Tsar Asen St., GSM: +359 8882939 13,E-mail:velstan@yahoo.com
}

national markets, the increased volumes of raw materials and end products, the provision of regular merchandising, the increased productivity at reduced costs, and the introduction of the ongoing working cycle (615). Serial production of standardized goods in small packages (as specific brands) distributed at low retail price came into play. The new trade philosophy became high sales volume at small profit margins. This stage is characterized by mass production that is legitimized and legalized by the mass marketing through national advertising of national brands investing huge budget amounts. Customers no longer trust the seller and trust the brand instead. The quality of products is guaranteed by their producers and not by the seller. Seduced by commercials, consumers start to consume trademarks and brand signatures instead of the objects themselves. Supermarkets start to appear and the very act of shopping becomes an exciting and satisfying activity for the middle class.

The second period began after the end of World War II with the rise of "The Affluent Society" as termed by John Kenneth Galbraith. The multiplied purchasing power democratized accessibility to emblematic products of the age (cars, television sets, household appliances, etc.) and led consumer dreams to extremes. The increased consumption and the new consumer finance practices allowed a wide range of social groups access to individualized material demand previously patronized only by elite groups; supermarkets were replaced by hypermarkets; 
market mechanisms flooded everyday life, policies for increasing products variety and shortening product life cycle emerged. The market itself differentiated and marketing turned to strategies for consumer segmentation based on demographic, communication, motivational, behavioral and socio-cultural factors. The Affluent Society propagated the notion of consumer happiness through marketing attraction, product innovation and change of models, styles and trends. Advertising created artificial needs, organized boundless profligacy, temptations and unrestrained stimulation of consumption wants. Consumption turned into a style of living and gave meaning to life.

The third period of consumer capitalism of liberal societies began in the late 1970s. It can be broadly defined as an age of hyperconsumption and commercialization of individual, emotional, physical, sensual and aesthetic need of communication, amusement and maintaining a healthy lifestyle. The period is also characterized by different selling, consumption and distribution techniques. Market goods and items are no longer a marker of social status and position within groups, but a means of independence, mobility, sensual experience, gaining experience, improving the quality of life, preserving ones' youth and health. The capitalistic system is surged by the informational technologies revolution, the market globalization and the financial deregulation. Demand dominates over supply. Marketing deifies the customer treating it as a tamed God whose needs must be identified and appeased in the name of preserving the functionality of the entire system where markets are ultra segmented, the goods and services are extremely differentiated, the quality is a top priority, selling new goods is radically accelerated and commercial communications - omnipresent.

Business organizations are globalising, the role of multinational companies widens, economic areas open up, the scope of merger and acquisition operations changes, market competition is taken to extremes - all these processes leading to one both logical and paradoxical outcome - the unification of world markets, the ranges of products and the hypermarket chains (invading all continents). Meanwhile, the economy focused on material goods transforms into service economy. Over the last few decades, marketers keep redefining their policies.

Here are some of the most obvious earmarks of this change.
THE NEW ADVERTISING PRIORITIES

In the age of hyper consumption, marketing communications, advertising in particular, boost the emotional attitude toward consumed goods and services giving priority to gained experience, and sensual change. Sensual marketing and experience marketing dominate and focus on communication techniques and strategies that trigger emotions, sensations and the imagination. A great emphasis is given to the emotional attractiveness, the experience of pleasure, play and recreation, eco-friendly, nature-protective and civic empathy. The front-runner in the hitherto prevailing communication functionality - is no longer treated as the basic determinant for consumer choice. Rational appeal using logical arguments and factual evidence to persuade individuals on the advantages of a given product is no longer the underpinning element in the marketing message. Instead, the hyper-consumer is craving for various sensations, sensual welfare and emotional adventures.

Hence, the new imperative is that it is not the product and the service that is on the market, but their image - adequately and purposefully generated through persuasive communication. In the very beginning of the 1960s, Reeves worked out his entire theory on USP (Unique Selling Point) by pointing out the importance of the product's brand name and its unique benefits in the advertising communication (16). Since a few decades, however, the emphasis has shifted from the product uniqueness to the uniqueness of its communication to the public and the meanings derived from such communication which overreach the objective reality of these goods and services, often having little to do with them $(17,18)$. Nowadays, an increasing number of world brands communicate everything else except the physical nature of their product (the advertising campaigns of the United Colors Of Benetton have nothing to do with clothes but with a specific vision, issue or a lifestyle associated with the brand). The target of such marketing is to establish a brand identity, the big switch being that the image imperative is displaced from the ambit of the company to the supply of marketing.

There is one more transformation. It is no longer the desire for social recognition that motivates high-end consumption but the hedonistic and narcissistic delight to derive satisfaction from the independently conceived positive image of one's own consumer Self. By all means, snobbery, the taste for ostentation and segregation have not been annihilated 
completely, but have definitely been restructured according to the subjective logic of individualism. Advertising still exploits models where by gaining pleasure for oneself (from buying particular clothes, cars, foods, drinks, accessories, etc.) the consumer gains the admiration of others, yet a much more exploited model these days is the one of the Self-complacency (L'Oreal - Because You're Worth It). Brand enthusiasm is fed by the sense of delight derived from the intimate experience and the comparison with other people in favour of one's own self, from the desire to stand out but without provoking envy. The sign brand gives privilege and comfort to the buyer, and its acquisition is not a means to rise in public esteem, but rather not to be considered inferior to other people (6: 41-43). This is why brand sensitivity is so evidently heightened among less wealthy young people. World famous brands yank out of obscurity, they are used as a way of demonstrating adequate participation in the games of fashion, youth and consumption. Young people build the code of their personality outside the social status and family borders.

One of the most striking evidence of the fall of conspicuous consumption is the consumer behaviour associated with health care products, services and expenditures. The minds of billions are occupied with health care. Not only do people consume medications, they also consume medical television programs, medical articles, medical guidebooks, medical forums, medical encyclopedias, medical websites, etc. Health care is nowadays of paramount importance for every age. It is no longer sufficient to treat medical conditions, consumers today need to identify the cause, prevent possible deviations, foresee the future, reorganize risk behaviour and habits.

Obsession with medical competence has pervaded everyday life and an increasing number of activities and spheres of existence acquire health care content, including foods, drinks, tourism, living conditions, cosmetics, etc. Health is a deciding factor for influencing consumer decision in modern marketing communications and stock phrases such as "harmless, eco-friendly, all-natural, organic, bio, preservatives free, etc. have become the new Hallelujah. The hyper consumer lives with hypochondriac fears, monitors their physical symptoms, experiences health anxiety and constant concern of their bodies, seeks health care, takes great care of oneself, fights diseases and risk factors on a daily basis.
And the most important. Online social networks, addictive mobile applications, facebook zombing, the credulity toward the truthfulness and authority of blog and forum communication seem perfect to disinform, mislead, manipulate, subject, dictate behaviour models and promote goods and services. Despite the multiple number of influence channels, however, despite the fact that smart phones have turned into all but a part of young people physical bodies, and that even the simplest mundane decisions are made after browsing the internet, an increasing number of voices argue that advertising in the 21 century (as an integral part of marketing communications) has lost its all-mightiness.

Is it really the case?

It seems that the popular idea of Galbraith about the reverse advertising pyramid is more real then ever $(19,20)$. Advertising communication programs consumer wants, promotes demand, imposes peremptory conditions on consumers, inundate them by floods of imperative images of happiness and identifies them with specific market goods, creates new wants, makes them standardized and dumb, deprives consumers from their autonomous decisions, at the same time deepening their dissatisfaction. In short advertising generates incessant wants, of goods and services, that consumers don't really need and production satisfies wants. As early as in the stage of the abundance society, there are many who unmask the totalitarian nature of advertising and perceive in its influence terror and programming of life, stigmatizing the imposed wants and their repressive satisfaction. It is exactly in the second period when the greatest number of theories on advertising as a creator of a new planetary slavery, perpetrator of massive frustrations and disappointments, symbol of the institutions enslaving people and their style of existence are developed. Although such theories can still be heard (for example, the comparison of brand expansion with cultural fascism and tyranny), there are certainly voices proclaiming exactly the opposite - that over the last decades a major change has occurred (6:159$160)$ ! It is a fact that the overall advertising costs constitute a decreasing value from the communication expenses of organizations who spend more on extra media presentation, PR, patronage, sponsorship, direct marketing, etc.

Have we reached the age of post-advertising society?

It is highly unlikely that we have! It is simply that advertising sets new objectives - bringing forward the value of the goods and services 
enriched with glorifying of a specific mindset, values and ideas (consumers are gained with slogans like: Nike - Just do it, Calvin Klein Be yourself, Apple - Think different...). Advertising used to create an exuberant image of the product, today it makes emotional connections with the brand. Contemporary advertising dictates consumer standards, influences an increasing number of individual and collective behaviour, communicates health, beauty, youth, losing weight, nutrition, personal development, pleasure, seeking and discovering one's own Self in society. This is the reason why nutrition experts blame advertising for obesity and overweight problems in young people (advertising, in turn, healthy nutrition practices and foods) just as feminists do claiming that the advertising industry urges tyrannic templates of female beauty or treat women as if they were kitchen robots childbound, housebound, and limited in horizons to cleaning, ironing and laundry. It is argued that the increase of family and individual bankrupts, bulimic shopping and consumer fever are connected to the augmented power of advertising, that tens of millions of households in Western Europe are heavily indebted but at the same time, almost every European indulges in impulsive purchases or purchases on a whim. However, civil bankrupts come not so much as a result from hyper consumption than from the high rate of divorces, job cuts, diseases and widowhood, besides addicted shoppers are a minority everywhere in Europe (6: 164 -167).

Contemporary advertising is rather a moderate authority than a totalitarian domination. Consumers are not hypnotized dummies contrived by communication experts. They sieve messages and eventually pay attention only to what concerns their personal interests and preferences. Indeed, the historical and social role of advertising in many respects is receding because it rules over a conquered territory. Even the classical "pedagogical" aspect of advertising has been reduced. While the decadal "copy strategy model" which basically goes down to an endless circulation of one and the same message (pinpointing on the functional or psychological advantages the product offers) where the consumer is an easily modeled passive subject is still exploited, the hyper consumer jaded by the look-alike goods and services, often allergic to the advertising compulsion demands a radically different kind of approach. Advertising is no longer taming masses in satisfying artificially created wants, it rather drums persistently cravings for amusement, comfort, innovations and lifestyle $(21,17)$. The cognitive worldview of Behaviorism (stimulus - response) is in retreat. From a mechanism for bringing out the value of goods and services advertising has turned into a constructive spectacle. It is audacious, provoking, even mocking and its aim is not particularly to praise but rather to excite, amuse, update, upgrade, rejuvenate the image and infatuate the consumer even only as a mass culture artefact. Advertising seeks participation, creates emotional intimacy, shares a system of values and its recipient is considered as a co-author of the advertising message.

Hyper-modern advertising has ceased to be a totalitarian system! It stimulates consumption wants falling in step with the trends and ideology of the age. It is not a creator of social and cultural transformation, it aggrandizes referential systems it has not created and which are already consensual and free from conflict. Advertising does not impose new roads, it adapts to the new social sensitivity.

\section{CONCLUSION}

The hyper consumer is distrustful and lacking perseverance in relation to brands due to the obsession with innovations, the break-up of fashions, the excessive saturation of primary needs and the very existence of hyper-choice. In this context, one of the interesting questions concerning mostly former socialist countries is their integration to the society of hyper consumption. Global realities of our time prove that it has already happened despite half a century-old planned economy and socialistic organization, despite the huge difference between the living standards and the GDP measures. This is a very different debate indeed, tangential to the main issues of this article, but the very integration proves that the dimensions of hyper consumption are, to a large extent, not only economic but also ideological and cultural reality. Hyper consumption is the new sense of identity and social self-realization of the individual which stands above the rigid markers from the past like social affiliation, profession or education. It seems that global marketing communications could not care less about the fact that Bulgarian wages and pensions are the lowest in EU. Here likewise, they set the scene for stimulating wants and advertising euphoria with splendid images of vacations and sexualized body signs. Here likewise compulsion is replaced by seduction, duty by hedonism, saving by expenditure and the promises about the future by the promises for "here and now". In Bulgaria likewise, despite low income and poor standard, the daily life of 
the "society of wants" is drenched and shaking with the image of consumer happiness, dreams of healthy life, shiny sea shores, music, fashion, erotica, young people, parties, innovative means of communication, etc. In Bulgaria likewise, due to product innovations, changing models and styles, advertising attraction and credit promotion, the entire economic machine speaks out - you consume, therefore you exist.

\section{REFERENCES}

1. Stanev, V., 2012. Modernism, postmodernism and their consumer dominance. In: Research methods and technologies in economic and social sciences. P. : UI „P. Hilindarski” (218-226).

2. Stanev, V., 2012. From the "brave new world" of Modernism, through postmodern "worries," to the glocal worlds - in search of the happiness of possession and consumption. In: Scientific papers - FISN, Tom 8, P.: UI „P. Hilindarski”. (423-444)

3. Stanev, V., 2013. The power over advertising and advertising as power. In: , Traditions, directions, challenges" Ton III. S.: UI „P. Hilindarski” - Smolyan (26-34).

4. Stanev, V., 2015. The Contemporary Consumption And The Human Body. B: TRAKIA JOURNAL OF SCIENCES, SZ::TJS Vol. 13, Supplement 1 (179-184)

5. Stanev, V., 2015. The Physical And Social Aspects Of The Human Body As A Reagent For The Consumption. In: TRAKIA JOURNAL OF SCIENCES, SZ: TJS, Vol. 13. Supplement 1 (185-190)

6. Lipovetsky, G. 2008. Le Bonheur Paradoxal. С.: Рива. 376 стр.
7. Bauman, Z. 1994. Intinations Of Postmodernity. B: Социологический журнал №4. 69-80.

8. Bauman, Z. 2004. Searching for a Centre that Holds. - In: M. Featherstone, S. Lash, R. Robertson (Editors). Global Modernities. S.: Kritika I Humanizam, 199-217.

9. Boudrillard, J. 1995. The Illusion of the End. S.: Kritika I Humanizam.

10.Ильин, И. 2000. Поведение потребителей. С.П.: Питер.

11.Lyotard, J. 2002. Moralites Postmodernes. S.: Kritika I Humanizam.

12.Taylor, C. 1999. The Malaise Of Modernity. S.: Kritika I Humanizam.

13. Therborn, G. 2004. Routes tothrough Modernity. - In: M. Featherstone, S. Lash, R. Robertson (Editors). Global Modernities. S.: Kritika I Humanizam, 177-198.

14.Habermas, J. 1999. The Philosophical Discourse of Modernity. P.: EA.

15.Heilbroner, R. 1997. $21^{\text {st }}$ Century Capitalism. S.: Kritika i Humanizam.

16. Reeves, R. 1961. Reality in Advertising. NY.: Alfred A. Knopf.

17. Stanev, V., 2013. The USP Concept - The Very End Or The Brand New Start Of Creativity In Advertising. B: TRAKIA JOURNAL OF SCIENCES, Vol 11, SZ (354-360).

18. Bondikov, V. 2007. Manipulations In Communication. S.: Siela

19.Galbraith, J.K.1998 The Affluent Society. 14 ed. NY: A Mariner Book

20.Galbraith, J.K. 1993. The Anatomy of Power. S.: Hristo Botev

21.Seguela, J. 2004. Hollywood Lave Plus Blanc. S.: Ividim 